(Potchefstroom University for Christian Higher Education)

\title{
ABSTRACT
}

\section{Ezekiel 18 and Human rights}

In South Africa the debate on Human Rights gained new impetus after the implementation of the interim constitution in 1994, followed by the new constitution in 1996, containing a charter of fundamental Human Rights. The question to be answered by this paper is whether Ezekiel 18 can contribute to this debate. This paper firstly discusses the question whether the Old Testament can be used in the debate on Human Rights. This is followed by a discussion of Ezekiel 18, with emphasis on the transgressions listed in this chapter in their Israelite context. Many of these injunctions are related to the laws of Deuteronomy, the Book of the Covenant and the Holiness Code. These injunctions are studied against the background of Israelite law in general and the three codes mentioned above in particular. Finally, the implications of Ezekiel 18 for the issue of Human Rights are discussed. The violation of rights of people guaranteed by divine law is seen as one of the major causes of divine punishment. God's law was meant to create a society found on justice. An unjust society is in contradiction to the will of God, according to Ezekiel 18. The implications of this view for the debate on Human Rights in South Africa need to be taken into consideration.

\section{INTRODUCTION}

In South Africa the debate on Human Rights gained new impetus after the implementation of the interim constitution in 1994, followed by the new constitution in 1996, containing a charter of fundamental Human Rights. It can indeed be called a highly politicised issue (Maritz, $2000: 28$ ). The question to be answered by this paper is whether Ezekiel 18 can contribute to this debate, to add a voice from the Old Testament to the many voices being heard. In this chapter individual responsibility is stressed in the process of passing judgement on the people of God. Individual responsibility is qualified by listing transgressions committed or refrained from by the people on an individual basis. These transgressions include the violation of religious and ethical injunctions. The list is repeated, with variations, three times in this chapter. Reference is made to religious transgressions, such as participating in the worship of idols, but the majority of matters mentioned are related to another person's wife or possessions, social justice and the just application of the laws of the land. This paper will firstly discuss the question whether the Old 
Testament can be used in the debate on Human Rights. This will be followed by a discussion of Ezekiel 18, with emphasis on the transgressions listed in this chapter in their Israelite context. Many of these injunctions are related to laws of Deuteronomy, the Book of the Covenant and the Holiness Code. These injunctions are studied against the background of Israelite law in general and the three codes mentioned above in particular. Finally, the implications of Ezekiel 18 for the issue of Human Rights will be discussed.

\section{THE OLD TESTAMENT AND HUMAN RIGHTS}

Human Rights can be defined in different ways. It is frequently associated with the rights of people over against the state and society and the protection of these rights (Vorster, 1999:56). This can be regarded as a definition in a political sense, whereas in the Bible one would expect a more theological approach to Human Rights, with emphasis on the value of humanity.

The first question to be answered is whether the Old Testament can indeed be used to shed light on the subject of Human Rights. This is partly related to the question whether the study of the Old Testament, especially Old Testament Theology or Old Testament Ethics, must be regarded as a descriptive discipline only, or whether it can also be regarded as prescriptive (cf Hasel, 1991:28-38). There are many different views on this issue. It is impossible to go into a detailed discussion of this problem. One can look at the problem in a more restricted sense by asking whether the Old Testament, or indeed, the Bible as a whole, can be of any use in the discussion of modern ethical and related problems. Even here a wide variety of views exist, as can be seen in the extensive work of Bilkes (1997). In an important article published in 1965, Long states that there is considerable agreement among Christians about the authority of Scripture for Christian ethics, but little agreement on the way in which it is authoritative (Long, 1965:149). He distinguishes three ways in which the Bible is used, as a law book (Long, 1965:148-154), as a source for principles or ideals (Long, 1965:154-148) or in relation to the concept of response in contextual or situational ethics (Long, 1965:158-162). Gustafson (1970) distinguishes four ways in which Scripture is used. The first two agrees with Long's first two. His third is the use of analogy (Gustafson, 1970:442). His fourth way is related to the variety that is encountered in Scripture, including a variety of moral laws, principles and norms. Moral judgement is then related to reflexive discourse on this variety (Gustafson, 1970:444). He regards the Bible as one among more bases for moral judgements (Gustafson, 1970:450). He rejects the idea of an authority based on verbal inspiration and, on the other hand, the idea that the Bible has no relevance (Gustafson, 1970:454). Scripture is, however, no final 
court of appeal on ethical matters (Gustafson, 1970:455). Still, for a Christian ethicist the acceptance of the authority of the Bible is the factor that makes him a Christian ethicist, even though there may be a dispute on what Scripture authorises and justifies (Childress, 1980:376). Botha (1999) also agrees that the Bible can be used in discussions on Human Rights, but states that this message can be ambiguous. He is of the opinion that the existence of bills of Human Rights may be regarded to a significant extent as part of the legacy of the Christian church (Botha, 1999:1101). The Bible must be regarded as the foundational document of the church, and as such forms one of the bases for ethical discussions (cf Botha, 1999:1103).

Dawkins (1997) gives a very negative answer to the question regarding the Bible's relevance in ethical discussions. In 1996 the Pope addressed the members of the Pontifical Academy of Sciences. This speech of the Pope was published (John Paul II, 1997), together with four commentaries on that speech, of which Dawkin's was one. In his message the Pope stressed that there should not be contradictions between science and revelation, as truth can not contradict truth (John Paul II, 1997:381). He also emphasised the used of "a rigorous hermeneutic for the correct interpretation of the inspired word" (John Paul II, 1997:382). In reaction to the message of the Pope, Dawkins raises the question whether religion in general "has some special expertise to offer us on moral questions" (Dawkins, 1997:397). He says that science can not answer questions of right and wrong. Even secular moral philosophy can not give the answer. He is, however, adamant that religion can not supply some solid bedrock in this regard. He says that no person uses scripture as ultimate authority, but at the most picks and chooses the nice bits and ignores the rest. He is also very negative about the "God of the Old Testament" (Dawkins, 1997:397-398). His alternative is some kind of liberal consensus. This consensus is not something absolutely fixed but rather changes over time (Dawkins, 1997:398).

There are also Christians who value the Bible, but who are very careful about the misuse of the Bible in the debate on Human Rights. A special danger in this regard is the use of the Bible to validate the idea of Human Rights post-constructively (Maritz, 2000:29). In this way the Bible could be used to bolster an already existing argument. Maritz $(2000: 37)$ warns against the use of the Bible to substantiate Human Rights on Scriptural grounds.

On the other hand, there are Christian ethicists who value the contribution of the Bible to ethical issues, in particular the contribution of the Bible with regard to the issue of Human Rights. WestmorelandWhite $(1997: 67,83)$ states very clearly that a Christian approach to Human Rights must be related to the central themes of biblical faith. 
With regard to Human Rights, Westermann, Otto and Braulik follow a more positive approach to the possibility of a contribution from the Old Testament. Westermann approaches the relation between the Old Testament and Human Rights in a very cautious manner. He makes it quite clear that Human Rights is a modern concern and that questions related to Human Rights can not be put directly to the Bible (Westermann, 1984:138). One can, however, ask whether that what the Bible says about God has any bearing on Human Rights. The question about Human Rights can thus be put indirectly to the Old Testament. He emphasises the importance of the pre-history in Genesis 1-11 in this regard (Westermann, 1984:139-142), pointing to humankind as created in the image of God. With regard to the legal material of the Old Testament, he states that the Old Testament does not know the notion that people have rights that belong to them, that they could lay claim to (Westermann, 1984:143). The possible relation between the laws of the Old Testament and Human Rights must again be indirect. There are tendencies in the legal material, which point in the direction of Human Rights. Of special importance are those indications that are related to the value of humankind (Westermann, 1984:145). With regard to the prophetic books, he emphasises those sections where the prophets interceded on behalf of the disadvantaged in society (Westermann, 1984:146).

Otto (1999:1) regards the Hebrew Bible as one of the most important sources of Human Rights. He sees two interrelated sources for the idea of Human Rights in the Old Testament, viz, the political theology as in Deuteronomy and the anthropology of creation theology (Otto, 1999:13). Otto refers to the two "tables" of Human Rights passed by the General Assembly of the United Nations in 1996 (1999:2). The first contains the classical civil rights related to political participation and personal freedom. These are related to protection of the individual against the state. The second "table" deals with economic, social and cultural rights. Otto is of the opinion that Deuteronomy had an important impact on this second field of Human Rights (1999:13). The ethical provisions of Deuteronomy could not be enforced by a court of law, but were dependent on the ethical responsibility of the people of Judah (Otto, 1999:14).

Botha (1999:1104) distinguishes between Human Rights as the legal protection of an individual against the state and the notions of human dignity and a just society. The idea of legal protection is a modern notion that can not be found in the biblical literature, while ideas on human dignity and a just society are present in almost all religions, from ancient times onwards. Human Rights in the first sense can not be found in the Bible, but the Bible can indeed shed important light on the second aspect. 
Braulik (1998) does not discuss the question of the use of the Old Testament in the debate on Human Rights, but compares some of the provisions in the Universal Declaration on Human Rights to legal material from Deuteronomy. He thinks it possible that Deuteronomy may have influenced the formulation of certain provisions in charters of Human Rights. In his article he looks especially at the concepts of liberty, equality and fraternity as they appear in Deuteronomy (Braulik, 1998:209-210). He has no problem of talking about Human Rights in Deuteronomy (cf Braulik, 1998:211). Human Rights in Deuteronomy can, however, not be divorced from faith in God. He says, for example, that freedom is not seen in Deuteronomy as something that belongs to humanity in its entirety, but that it is based on a free act of God in history (Braulik, 1998:211). This freedom is not granted to an individual, but is granted only in the context of a new society founded by God (Braulik, 1998:212). The laws in Deuteronomy have a bias in favour of the weak and poor people in society (Braulik, 1998:217). An example of this is the right of a slave to escape from an inhumane master (Braulik, 1998:219). Equality before the law is another basic concept in Deuteronomy (Braulik, 1998:221). Human Rights in Deuteronomy can, however, not be isolated from the believing society. In this sense it is different from the modern ideas of Human Rights related to the autonomous human nature (Braulik, 1998:226).

Botha is convinced that the Bible can be used in a positive way to promote Human Rights and a just society (1999:1118). The attempt to link Ezekiel 18 and Human Rights in this paper is related to Botha's proposal to have an interaction between reflection on specific Human Rights and the reading of specific biblical passages (1999:1121). The context of the original must, however, be kept in mind. All the laws of the Old Testament must, for example, be read as duties laid upon humankind within the context of the covenant, which binds people to God and their neighbours (cf Ahern, 1984:301-302). In this way the Bible is not used to substantiate Human Rights, but rather to address issues that may also be relevant for the debate on Human Rights.

\section{EZEKIEL 18 AND TRANSGRESSION OF THE LAW}

It is impossible to give a detailed analysis of Ezekiel 18 in this paper. The emphasis will be on the transgressions referred to and their relation to Israelite law. This chapter must not be regarded as a radical innovation, but it is rather a logical development of what can be regarded as a central thesis of Old Testament faith (cf Wright, 1983:201). The genre can be regarded as a prophetic version of a priestly ruling (Allen, 1994:267). The chapter is generally regarded as an extended disputation speech (e g Block, 1997:554 and Zimmerli, 1979:374). Some disagreement exists about the structure of the chapter. The most common view is 
the one expressed by Cooper (1994:187-188). He divides the chapter in two sections, 1-20 and 21-32. The first section states that individuals are not responsible for the sins of their fathers. It can be divided in two subsections, viz, 1-4 stating the thesis, with three practical examples in 5-20. Verse 20 is a summary of the first division and a preview of the second. The second section, 21-32, states that individuals are also not bound by their own former sin, but could change the situation through repentance and faith. The thesis is again stated first (in verses 21-24). This is followed by a reaction to a charge of divine injustice in verses 25-29. The chapter is concluded with a call to repentance in verses 30-32. Similar divisions can be found in Cooke (1970:194) and, more detailed, Aalders (1955:295-305) and Allen (1994:270).

Block (1997) proposes a different structure. He disagrees with the general opinion and thinks that three important quotations of popular opinion in the chapter are the primary indicators of structure. These quotations appear in verses 2, 19 and 25 (Block, 1997:554). The quotation in verse 2 is the well-known one on the sour grapes. In verse 19 a question of the people is quoted: Why does a son not carry the guilt of his father? In verse 25 the people are quoted as reproaching the Lord: The way of the Lord is not correct. Block says that these three sayings introduce different lengthy prophetic speeches. He is, however, not very consistent in his division of the chapter, which can be summarises as follows according to the headings he supplies in his commentary (Block, 1997:55-589):

a Closing the Door on Cosmic Fatalism (18:1-18)

(1) Preamble and Thesis: The Illusion (18:1-2)

(2) The Counterthesis: The Reality (18:3-18)

(a) The Principle of Divine Justice (18:3-4)

(b) Three Case Studies in Divine Justice (18:5-18)

(i) The Case of the Righteous Person (18:5-9)

(ii)The Case of the Wicked Son (18:10-13)

(iii) The Case of the Righteous Son (18:14-18)

(3) The rejoinder and Reply (18:19-20)

(a) The Question of Divine Justice (18:19a)

(b) The Answer (18:19b-20)

Opening the Door on Divine Mercy (18:21-32)

(1) The Two ways (18:21-24)

(2) The Call to Repentance (1825-32)

(a) The Rejoinder and Reply (18:25-29)

(b) Epilogue (18:30-32)

In this division he also follows the division in two sections (1-20; 21 32 ). He does also not deal with the repetition of the third saying in verse 
29. As a result of this inconsistency, Block's proposal can not be regarded as an improvement on the general consensus.

Zimmerli (1979:374) sees the whole of the chapter as a response to the popular saying at the beginning. Zimmerli links the section about the sequence of righteous - unrighteous - righteous to case law (Zimmerli, 1979:375). The whole sequence wants to emphasise the link between righteousness and life (Zimmerli, 1979:379). As a disputation, this chapter presents the normal elements of that genre, viz, thesis, counterthesis and dispute. The thesis is the saying of verse 2 , the counterthesis is the affirmation that the person who sins, will die and that the righteous will live. The dispute is the denial of the thesis, as in verses 3-4a, 10-13 and 14-17 (cf Allen, 994:268). The three lists of transgressions are used to motivate the counterthesis in the dispute. The aim of the whole dispute can be linked to the final call to repentance at the end of the chapter (Allen, 1994:268).

The first list of transgressions (vss 5-9) is the longest of the three. The list is phrased in a casuistic way, just as many of the complex laws in Leviticus. The whole complex of verses 5-9 must be read as one long, complex casuistic construction. It commences with a general case in verse 5 . This is then expanded on in detail in verses 6-8. The protasis is summarised at the beginning of verse 9, again in general terms, with the apodosis at the end of verse 9 . With regard to the detail of what righteousness entails, thirteen statements can be distinguished:

- He does not eat on the mountains; (1)

- He does not lift his eyes up to the idols of the house of Israel; (2)

- He does not defile the wife of his neighbour; (3)

- He does not make a sexual advance on a menstruating woman; (4)

- He does not oppress anyone; (5)

- He returns the pledge he took as surety; (6)

- He does not commit robbery; (7)

- He gives his bread to the hungry; (8)

- He covers the naked with clothes; (9)

- He does not lend with interest; (10)

- He does not make a profit; (11)

- He keeps his hand back from injustice; (12)

- He gives a fair judgement between people. (13)

For the purpose of this paper the other two lists will not be studied in detail. They omit some of the items, change the order in some cases, but do not add anything substantial to the list. For a summary of the three lists in tabular form, compare Block (1997:566).

Many authors see a link between the lists of Ezekiel 18 and a priestly style. Joyce (1989:41) makes special reference to Leviticus 19:11 and following. Block (1997:564-565) links the priestly style to the 
casuistic style used for the first list, the catalogue of crimes as for example in Leviticus 19, the form of the verdict in verse 9 and the form of the sentences in verses 9,13 and 18. Block also postulates a link between Ezekiel's list and a royal code of honour. Zimmerli (1979:375376) wants to link the section to certain temple rites at the cult, specifically to a priestly declaration in a gate liturgy with regard to a pilgrim. The specific setting is not that important for the present discussion, but the connection to priestly material is evident.

With regard to the thirteen transgressions listed in verses 6-8, six groups of injunctions (five pairs and a triplet) are normally distinguished. For example, Zimmerli (1979:379-380) relates the first pair (1 and $2^{1}$ ) to right worship, the second pair (3 and 4) to ritual regulations, pairs 3-5 (5-11) to ordinances of social life and legal activity and the last pair (12 and 13) to the sphere of law. Allen (1994:274) divides the 13 statements into five categories. 1 and 2 are of a cultic nature and could be related to the first commandment. 3 and 4 are about sexual acts that would cause cultic impurity. Allen regards 5 as a general statement, with 6 and 7 examples of that general statement. 6 is related to the restoration of a collateral pledge after the payment of debt and 7 deals with the seizure of the property of the poor by the rich. 8 and 9 are positive and relate to kindness that must be shown to the disadvantaged. 10 and 11 have the same intent. The last two (12 and 13) are also generalising. Injustice and fair judgement are related not only to a court of law, but have a wider meaning as a summary of the inhumanity listed in verses 68.

Cooper (1994:190) distinguishes five principles in the example of the righteous person who does what is right: to do what is just and right (v 5), to worship Yahweh alone (6a), to maintain moral fidelity and moral purity (6b), to be a good neighbour (7-8) and to respect and observe divine and human law (9).

Zimmerli (1979:380) finds many parallels between the list of Ezekiel and laws in the books of Deuteronomy and Leviticus, especially the Holiness Code. Cooke (1970:198) sees more influence from the side of Deuteronomy. It is impossible to discuss all the correspondences between Ezekiel's list and the law-codes in detail. A few representative examples must suffice.

The first pair of injunctions ( 1 and 2 ) is related to religious matters. The reference to eating on the mountains is clearly linked to Canaanite rituals on the high places. Zimmerli (1979:380) regards the formulation as peculiar to Ezekiel. Exodus 34:18 also uses the verb "to eat" in the same way as here. In the Holiness Code, Leviticus 19:26 can

${ }^{1}$ The numbers in brackets refer to the numbers given to the statements in the list above, for ease of reference. 
be compared to this statement, as can also be seen from the emendation of Ezekiel proposed by BHS, wanting to change "on the mountains" to "with the blood". The word ההרים is used in Deuteronomy 12:2 to refer to the high places of the Canaanites. The second injunction is related to the general prohibition to make images of God (cf Exodus 20:23 in the Book of the Covenant and Leviticus 19:4 and 26:1 in the Holiness Code). The Israelites had to destroy the idols of the Canaanites, not copy them (Deuteronomy 7:25). The noun for "images" is used in Leviticus 26:30 with regard to the idols of the Israelites that will be destroyed by the Lord. This passage in Ezekiel could be an allusion to that statement.

The second pair ( 3 and 4 ) is related to ritual matters, with very close parallels in the Holiness Code in Leviticus 18:19 and 20, where the same two matters are also discussed together. These injunctions also serve to protect the wife of another man, as well as one's own wife, against actions that would be detrimental to the woman.

The third group (5-7) consists of an introduction and two specific examples. The general rule at the beginning is very closely related to Leviticus 25:17 in the Holiness Code, where it is linked to the Year of Jubilee. In Exodus 21:20 the same idea is expressed, linked to the stranger. In Deuteronomy 23:17 (MT) it is used with reference to an escaped slave and in Deuteronomy 24:14 with regard to a hired labourer. The pledge and robbery referred to in the two concrete examples ( 6 and 7) are probably both related to something taken as pledge for a loan. Leviticus 5:21-26 is an example of legislation dealing with these matters. In the Book of the Covenant Exodus 22:25-26 (MT) also deals with a pledge. Compare also Deuteronomy 24:10-13 and 17. The noun occurs only in the sense of Ezekiel 18 in Leviticus 5:23 outside of Ezekiel. The verb related to this noun occurs in a similar context in the Holiness Code in Leviticus 19:13.

The positive statements 8 and 9 deal with providing for the poor. There are no laws giving instructions directly related to these two provisions, but there are many general laws dealing with taking care of those in need, like the provisions regarding leaving a part of the harvest behind for the poor (Lev 19:9-10, 23:22 and Dt 24:19-22) or helping those in need (Dt 14:29 and 15:7-11). Deuteronomy 10:18 is, however, very important for these two statements. That verse describes the Lord as the one who gives food and clothes to the needy.

The difference between תברית in in verse 8 (10 and 11) is not so clear. De Vaux (1976:170) thinks it possible that the former might refer to a loan of money and the latter to a loan in kind. Exodus 22:24 (MT) states that interest may not be taken from a poor person. Deuteronomy 23:20 prohibits taking interest from a member of the people of Israel but allows it for a stranger. A very close parallel to statements 10 and 11 appears in Leviticus $25: 35-37$. Verse 36 is the only place where 
occurs apart from Ezekiel 18, except if the word מרבית is emended to תרבית in verse 37 . Verse 37 also refers to money and kind borrowed by a person, supporting De Vaux's idea of the distinction between the two words.

The last two statements are related to unlawful action in a court of law (Zimmerli, 1979:381). Very close parallels appear in Leviticus 19:15 and 35. Compare also Exodus 23:1-3 and Deuteronomy 16:18-20.

If one looks at all the parallels discussed above, it is clear that the statements of Ezekiel 18 can be related to laws in the three law-codes. In particular, there are a number of very close parallels in the Holiness Code, but the list of Ezekiel 18 cannot be linked to one code only. This list reflects a tradition, probably of priestly origin, of right and wrong conduct on the side of the people of God.

\section{EZEKIEL 18, INDIVIDUAL RESPONSIBILITY AND HUMAN RIGHTS}

One must remember that Ezekiel 18 does not deal with Human Rights directly. It deals with divine retribution (Joyce, 1989:38). Ahern (1984:310) emphasises the role of the prophets in bringing to Israel's attention the idea of individual responsibility. They had to realise that each person is accountable for every aspect of his life, as can be deduced inter alia from Ezekiel 18. Ezekiel appeals to a familiar standard of right and wrong (Cooke, 1970:198). This standard was meant to determine the people's relation to God, but also their relation to one another. In this standard there is no clear division between what is directed at ones relation with God and ones relation to your neighbour. These two relationships are closely related in Old Testament religion. This is made very clear by the basic doctrine of the Holiness Code, viz, that the people must be holy because the Lord is holy (cf Lev 19:2). This means, however, that when one "person transgresses against another, he is also transgressing against God. The rights of another person are also granted by God and will be protected by him. Ezekiel 18 emphasises that every person is responsible for his own actions. These actions include a person's conduct towards other people.

Some of the matters mentioned in the list in Ezekiel 18 belong exclusively to the religious sphere, like the first pair. The Lord requires that the people must be absolutely loyal to him. If this is not the case, their relationship to one another will be affected as well. The second pair is related to cultic purity, because the defilation of a neighbour's wife and sexual advances to a menstruating woman would result in impurity. On the other hand, by refraining from doing what this pair mentions, a person would prevent problems for another person, his own wife or the wife of his neighbour, as the case may be. 
The next seven matters mentioned in Ezekiel's list are all related to the rights of people, especially poor people. The general statement about oppressing people sets the tone not only for the two statements directly following it, but also for the whole series dealing with the protection of and care for the disadvantaged. One must remember that in the time of Ezekiel the people were in exile and they did not have their own free government to uphold their laws. They were part of the Babylonian Empire and thus subjected to Babylonian Law. The actions prescribed by the Israelite Law Codes did not have the sanction of their own courts anymore. They had to make a conscious decision to keep their own laws with regard to caring for the disadvantaged in their own community. Protection against the Babylonian state was not the concern of their law codes, but rather the regulation of the life of God's people, even when under foreign domination. In accordance with this, the injunctions mentioned by Ezekiel included positive statements about caring for the disadvantaged, in addition to the normal negatively formulated injunctions to refrain from certain actions. Helping the poor by lending them money and taking care of their needs for food and clothing would be the humane action required of God's people. In this way the image of God would be protected in people. The reference to just action must be read against the background of a court of law, but still it serves as a warning to the people as well. If they did not take care of the needs of the disadvantaged, they could not expect God to take care of them. They would suffer punishment from the hand of the Lord - divine retribution for their failure to protect the rights of other people - their responsibility. In this way the rights of the people of God received divine sanction.

\section{CONCLUSIONS}

The violation of rights of people guaranteed by divine law is seen as one of the major causes of divine punishment. God's law was meant to create, in Israel, a society found on justice, with respect for the rights of other people. An unjust society is in contradiction to the will of God, according to Ezekiel 18. The implications of this view for the debate on Human Rights in South Africa need to be taken into consideration. A chapter on fundamental rights in a constitution will not have any meaning if a culture of respect for the rights of other people does not exist in the hearts and minds of the people.

\section{Consulted literature}

Aalders, G Ch 1955. Ezechiël I. (Commentaar op het Oude Testament.). Kampen: Kok.

Ahern, B M 1984. Biblical doctrine and the rights and duties of man. Gregorianum, 65 (3-2):327-336).

Allen, L C 1994. Ezekiel 1-19 (Word Biblical Commentary 28). Dallas: Word Books. 
Bilkes, L W 1997. Theological ethics and Holy Scripture: the use of Scripture in the works of James M Gustafson, Paul Ramsey, and Allen D Verhey. Heerenveen: Groen.

Block, D I 1997. The Book of Ezekiel Chapters 1-24 (The New International Commentary on the Old Testament). Grand Rapids: Eerdmans.

Botha, J 1999. Biblical perspectives on the ministry and mission of the church with special reference to human rights. Hervormde Teologiese Studies, 55(4): 1098-1129.

Braulik, G 1998. Deuteronomy and human rights. Skrif en Kerk, 19(2):207-229.

Childress, J F 1980. Scripture and Christian ethics. Some reflections on the role of Scripture in moral deliberation and justification. Interpretation, 34:371-380.

Cooke, G A 1970. The Book of Ezekiel (International Critical Commentary). Edinburgh: Clark.

Cooper, L E 1994. Ezekiel (The New American Commentary 17). Nashville: Broadman \& Holman.

Dawkins, R 1997. The Pope's message on evolution and four commentaries. III. Obscurantism to the rescue. Quarterly Review of Biology 72(4):397-399.

De Vaux, R 1976. Ancient Israel. Its life and institutions. London: Darton, Longman $\&$ Todd.

Gustafson, J M 1970. The place of Scripture in Christian ethics: a methodological study. Interpretation, 24:430-455.

Hasel, G F 1991. Old Testament Theology: Basic issues in the current debate. $4^{\text {th }}$ edition Grand Rapids: Eerdmans.

John Paul II 1997.The Pope's message on evolution and four commentaries. Message to the Pontifical Academy of Sciences. Quarterly Review of Biology, 72 (4):381-383.

Joyce, P 1989. Divine initiative and human response in Ezekiel (Journal for the Study of the Old Testament Supplement Series 51). Sheffield: JSOT Press.

Long, E R 1965. The use of the Bible in Christian ethics. Interpretation, 19:149-162.

Maritz, P J 2000. Human rights, politics, faith and church. Nederduitse Gereformeerde Teologiese Tydskrif 41(1 \& 2):28-38.

Otto, E 1999. Human Rights: the influence of the Hebrew Bible. Journal of Northwest Semitic Languages 25 (1):1-20.

Vorster, J M 1999. The Reformed tradition and human rights. Studiae historicae ecclesiasticae 225(2):56-90.

Westermann, C 1984. Das Alte Testament und die Menschenrechte. In Westermann, C. Erträge der Forschung am Alten Testament. Gesammelte Studien 3. München: Kaiser, 139-151.

Westmoreland-White, M L 1997. Contributions to Human Rights in Dietrich Bonhoeffer's Ethics. Journal of Church and State 39(1):67-83.

Wright, C J H 1983. An eye for an eye. The place of Old Testament ethics today. Downers Grove: InterVarsity Press.

Zimmerli, W 1979. Ezekiel l (Hermeneia). Philadelphia: Fortress. 